\title{
Nintedanibo tyrimų rezultatai ịrodė veiksmingumą gydant plataus spektro fibrozuojančias intersticines plaučių ligas
}

\author{
CLINICAL TRIALS HAVE PROVEN THE EFFECTIVENESS OF NINTEDANIB TO TREAT A \\ WIDE RANGE OF FIBROSING INTERSTITIAL LUNG DISEASE
}

\author{
VIRGINIJA KALINAUSKAITE்-ŽUKAUSKE் \\ LSMU MA Pulmonologijos klinika
}

\begin{abstract}
Santrauka. Nintedanibas - tai tirozino kinazès inhibitorius, skiriamas idiopatinei plaučių fibrozei gydyti. Jo veiksmingumas įrodytas klinikiniuose tyrimuose. Vis tik fibrozuojančių intersticinių plaučių ligų yra ir daugiau, tačiau gydymo galimybės ribotos. Kadangi tiek idiopatinès plaučių fibrozès, tiek kitų fibrozuojančių intersticinių plaučių ligų patofiziologiniai procesai turi panašumų, atlikti ikiklinikiniai ir klinikiniai tyrimai parodè, kad nintedanibas gali būti veiksmingas plačiam fibrozuojančių intersticinių plaučių ligų spektrui.

Reikšminiai žodžiai: nintedanibas, su sistemine skleroze susijusi intersticinè plaučių liga, fibrozuojančios intersticinės plaučių ligos, FVC.

Summary. Nintedanib is a tyrosine kinase inhibitor used to treat idiopathic pulmonary fibrosis. Its effectiveness has been proven in clinical trials. Still, there are more fibrosing interstitial lung diseases, but treatment options are limited. Because of the similarities in the pathophysiological processes of both idiopathic pulmonary fibrosis and a number of fibrosing interstitial lung diseases, preclinical and clinical studies have shown that nintedanib may be effective in a wide range of fibrosing interstitial lung diseases.
\end{abstract}

Keywords: nintedanib, systemic-sclerosis associated interstitial lung disease, fibrosing interstitial lung diseases, FVC.

DOI: https://doi.org/10.37499/PIA.766

\section{IVADAS}

Nintedanibas - tai viduląstelinis tirozino kinazès inhibitorius, jis yra priešfibrozinis vaistas, patvirtintas idiopatinei plaučių fibrozei gydyti [1]. Atliktų tyrimų duomenimis, vaistas veiksmingai sulètina šios ligos progresavimą, forsuotos gyvybinès plaučių talpos (angl. forced vital capacity, FVC) mažèjimo greitị, paūmèjimų dažnit, nepriklausomai nuo sergančiųjų amžiaus, lyties ir plaučių funkcijos [2-6]. Gydymas nintedanibu yra saugus. Dažniausiai pasireiškiantis nepageidaujamas poveikis - viduriavimas, dèl kurio gydymas nintedanibu laikinai nutraukiamas arba sumažinama jo dozè tik mažai daliai pacientų. Nors nintedanibo veiksmingumas ịrodytas sergant idiopatine plaučių fibroze, tačiau fibrozuojančių plaučių ligų yra daugiau. Deja, pastarosioms esamų priešfibrozinių vaistų veiksmingumas nèra pakankamai ištirtas. Nors priežastiniai veiksniai yra skirtingi, tačiau patofiziologiniai procesai turi panašumų [7-10]. Ikiklinikinių tyrimų metu nustatyta, kad nintedanibas pasižymi priešfibroziniu ir priešuždegiminiu poveikiu gydant su sistemine skleroze susijusią intersticinę plaučių ligą $[1,10-16]$, taip pat kitas fibrozuojančias intersticines plaučių ligas $[1,10,12$, 15-18]. Toliau pateikiami naujausi klinikiniai tyrimai.

\section{SENCIS TYRIMAS}

Žinoma, kad su sistemine skleroze susijusios intersticinès plaučių ligos eiga yra nevienoda, vis dèlto daugeliui pacientų liga progresuoja, FVC mažèja, didejja mirties rizika [19-21]. Siekiant išsamiau ịvertinti nintedanibo saugumą ir veiksmingumą gydyti intersticinę plaučiu ligą, susijusią su sistemine skleroze, atliktas atsitiktinių imčių, dvigubai aklas, placebu kontroliuotas klinikinis tyrimas SENCIS [22]. Sistemine skleroze sergantys pacientai, kuriems pirmieji ne Raynaud sindromui būdingi simptomai pasireiškè per pastaruosius septynerius metus, o, atliekant didelès skiriamosios gebos kompiuterinès tomografijos tyrimą, plaučių fibrozès plotai sudarè mažiausiai 10 proc. (patvirtinus gydytojui radiologui ekspertui intersticinių plaučių ligų srityje), atsitiktine tvarka santykiu 1:1 suskirstyti i grupes. Vieniems buvo skirta išgerti $150 \mathrm{mg}$ nintedanibo du kartus per parą (nintedanibo grupè), kitiems - placebas analoginiu režimu (placebo grupè). Pirminè vertinamoji baigtis buvo metinis FVC sumažejjimo greitis (tyrimo metu vertintas per 52 savaičių laikotarpi). Svarbiausios antrinès vertinamosios baigtys buvo balų, apskaičiuotų pagal modifikuotą Rodnano odos pažeidimo skalę ir šv. Jurgio kvėpavimo klausimyną (angl. St. George’s 
Respiratory Questionnaire, SGRQ) pokytis per 52 savaites nuo pradinio, apskaičiuoto tyrimo pradžioje. I tyrimą itraukti pacientai, kurių FVC buvo ne mažesnis kaip 40 proc. būtinojo dydžio, o plaučių difuzinis pajègumas anglies monoksidui, koreguotas pagal asmens hemoglobino kieki kraujyje (angl. diffusing capacity for carbon monoxide corrected for hemoglobin, $\left.\mathrm{D}_{\mathrm{LCO}}\right)$ - 30-89 proc. būtinojo dydžio. Tyrime galèjo dalyvauti ir tie pacientai, kurie vartojo prednizoloną iki 10 mg per parą arba mikofenolato, arba metotreksato pastovią dozę mažiausiai 6 mèn. (arba abiejų vaistų derini) iki tyrimo pradžios. Tiriamųjų duomenys pateikiami 1 lenteleje. Jei tyrimo metu pasireiškè kliniškai reikšmingas sisteminès sklerozès pablogèjimas, buvo leidžiamas pridètinis gydymas.

Iš viso 576 pacientai gavo bent vieną nintedanibo arba placebo dozę; 51,9 proc. sirgo difuzine odos sistemine skleroze, 48,4 proc. tyrimo pradžioje vartojo mikofenolatą. Atliekant pirminę vertinamų baigčių analizę, koreguotas metinis FVC pokytis buvo $-52,4 \mathrm{ml}$ per metus nintedanibo grupejje ir -93,3 $\mathrm{ml}$ per metus placebo grupeje (skirtumas - 41,0 ml per metus; 95 proc. pasikliautinasis intervalas (PI) 2,9-79,0, $\mathrm{p}=0,04)$ (1 pav.). Modifikuotos Rodnano odos skalès balas ir bendras SGRQ balas 52 tyrimo savaitę grupèse reikšmingai nesiskyrè (skirtumai buvo -0,21, 95 proc. PI -0,94-0,53; $\mathrm{p}=0,58$ ir 1,69, 95 proc. PI, -0,73-4,12). Viduriavimas buvo dažniausiai pasitaikantis nepageidaujamas poveikis ir pasireiškė 75,7 proc. pacientų nintedanibo grupeje, 31,6 proc. - placebo grupeje (nepageidaujami poveikiai pateikiami 2 lentelèje).

Tyrimo duomenys parodé, kad pacientų, sergančiu intersticine plaučių liga, susijusia su sistemine skleroze, metinis FVC sumažéjimo greitis buvo mažesnis vartojant nintedanibą nei vartojant placebą. Klinikinè nintedanibo nauda kitoms sisteminès sklerozès apraiškoms nenustatyta. Nepageidaujamų nintedanibo poveikių profilis šiame tyrime buvo panašus ị ankstesnių tyrimų, kuomet vertintas jo poveikis sergantiesiems idiopatine plaučių fibroze [2-6].

Placebą vartojusių pacientų metinis FVC mažejjimo greitis SENCIS tyrime buvo mažesnis nei pacientų, sirgusių idiopatine plaučių fibroze ir vartojusių placebą INPULSIS tyrimuose 11 (-93,3 ml SENCIS tyrime, palyginti su-223,5 ml INPULSIS tyrime), nintedanibopoveikis lètinti FVC mažejimo greitit, palyginti su placebu, buvo panašus (atitinkamai - 44 proc. ir 49 proc.).
1 lentelè. Demografiniai ir klinikiniai tiriamujų duomenys [22]

\begin{tabular}{|c|c|c|}
\hline Charakteristika & $\begin{array}{c}\text { Nintedanibo } \\
\text { grupè }(n=288)\end{array}$ & $\begin{array}{l}\text { Placebo grupé } \\
\quad(n=288)\end{array}$ \\
\hline Moteriškoji lytis, n (proc.) & $221(76,7)$ & $212(73,6)$ \\
\hline Amžius, metais & $54,6 \pm 11,8$ & $53,4 \pm 12,6$ \\
\hline Difuzinė odos sisteminė sklerozė, n (proc.) & $153(53,1)$ & $146(50,7)$ \\
\hline $\begin{array}{l}\text { Metai nuo pirmujų ne Raynaud sindromui bū- } \\
\text { dingų simptomy̨ atsiradimo, vidurkis (intervalas) }\end{array}$ & $3,4(0,3-7,1)$ & $3,5(0,4-7,2)$ \\
\hline $\begin{array}{l}\text { Plaučių fibrozès dydis, vertinant didelès skiria- } \\
\text { mosios gebos kompiuterinès tomografijos tyri- } \\
\text { mo duomenis, proc. }\end{array}$ & $36,8 \pm 21,8$ & $35,2 \pm 20,7$ \\
\hline $\mathrm{FVC}, \mathrm{ml}$ & $2459 \pm 736$ & $2459 \pm 736$ \\
\hline FVC, proc. būtinojo dydžio & $72,4 \pm 16,8$ & $72,7 \pm 16,6$ \\
\hline Dıco, proc. būtinojo dydžio $†$ & $52,9 \pm 15,1$ & $53,2 \pm 15,1$ \\
\hline $\begin{array}{l}\text { Nustatyti antitopoizomerazès antikūnai, } \\
\text { n (proc.) } \neq\end{array}$ & $173(60,1)$ & $177(61,5)$ \\
\hline $\begin{array}{l}\text { Modifikuotos Rodnano odos pažeidimo skalès } \\
\text { balas § }\end{array}$ & $11,3 \pm 9,2$ & $10,9 \pm 8,8$ \\
\hline $\begin{array}{l}\text { - Pacientai, sergantys difuzine odos sistemine } \\
\text { skleroze }\end{array}$ & $17,0 \pm 8,7$ & $16,3 \pm 8,9$ \\
\hline $\begin{array}{l}\text { - Pacientai, turintys ribotą odos sisteminę } \\
\text { sklerozę }\end{array}$ & $4,9 \pm 4,2$ & $5,4 \pm 4,1$ \\
\hline Bendras šv. Jurgio kvėpavimo klausimyno balasף & $40,7 \pm 20,2$ & $39,4 \pm 20,9$ \\
\hline Gydomi mikofenolatu, n (proc.) & $139(48,3)$ & $140(48,6)$ \\
\hline Gydomi metotreksatu, n (proc.) & $23(8,0)$ & $15(5,2)$ \\
\hline
\end{tabular}

- plaučiu difuzinis pajègumas anglies monoksidui (angl. diffusing capacity for carbon moskaičius; FVC - forsuota gyvybinè plaučių talpa (angl. forced vital capacity). o nustatytos 285 nintedanibu gydytiems pacientams ir 284 pacientams placebo grupejje. Duomenys apie antitopoisomerazès antikūnus buvo renkami iš medicininès dokumentacijos. tokiu duomenų nebuvo, tuomet buvo atliekami tyrimai centrinejje laboratorijoje. odo ryškesnę odos fibrozę. Šie duomenys gauti 288 pacientams nintedanibo grupejje ir 286 pacebo grupeje. Difuzine odos sistemine skleroze sergantiems pacientams šie 列 144 placebo grupeje. Sergantiesiems ribota odos roze balai buvo gauti 135 iš nintedanibo ir 142 iš placebo grupès pacientų.

Bendrai SGRQ balai gali būti nuo 0 iki 100. Aukštesni balai rodo blogesnę su sveikata susijusią gyvenimo kokybę. Rezultatai buvo gauti iš 282 pacientu, gydytų nintedanibo grupèje, ir iš

\section{IN BUILD TYRIMAS}

Atliktas dvigubai aklas, placebu kontroliuotas 3 fazès klinikinis tyrimas IN BUILD [23]. Dalyvavo 15 šalių pacientai, sergantys fibrozuojančia plaučių liga, kai didelès skiriamosios gebos kompiuterinès tomografijos tyrimu nustatyta fibrozé, apimanti daugiau nei 10 proc. plaučių tūrio. Tiriamieji buvo suaugusiojo amžiaus ir su jau nustatyta fibrozuojančia intersticine plaučių liga. Atsitiktine tvarka skirta išgerti $150 \mathrm{mg}$ du kartus per parą nintedanibo arba tuo pačiu režimu ir doze placebo. Visiems tiriamiesiems, nepaisant gydymo, per paskutinius 24 mèn. buvo nustatytas intersticinès plaučių ligos progresavimas ir FVC buvo mažesnis kaip 45 proc. būtinojo dydžio numatytos vertès, $\mathrm{D}_{\mathrm{LC}} \mathrm{O}$ svyravo nuo 30 iki $<80$ proc. būtinojo dydžio. Randomizacija buvo stratifikuojama pagal intersticinių plaučių ligų radiologinès diagnostikos kriterijus atliekant didelès skiriamosios gebos kompiuterinę tomografiją 


\section{Farmakoterapija}

A

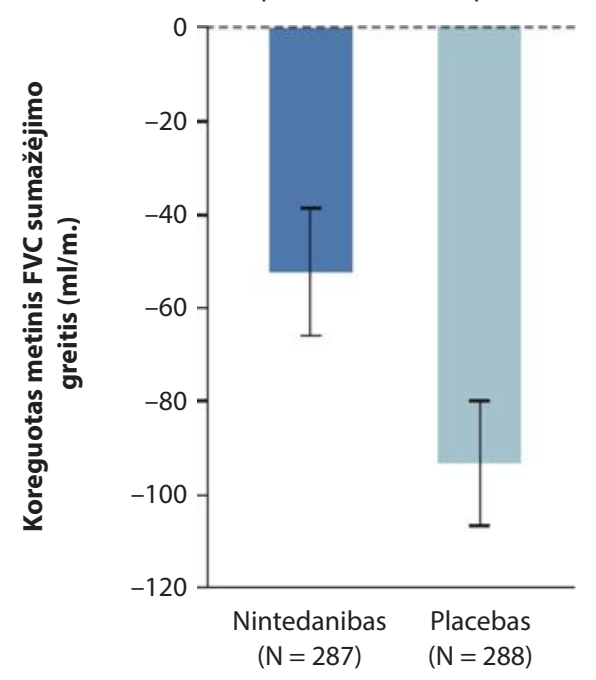

B

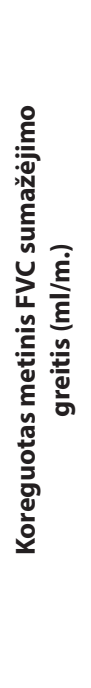

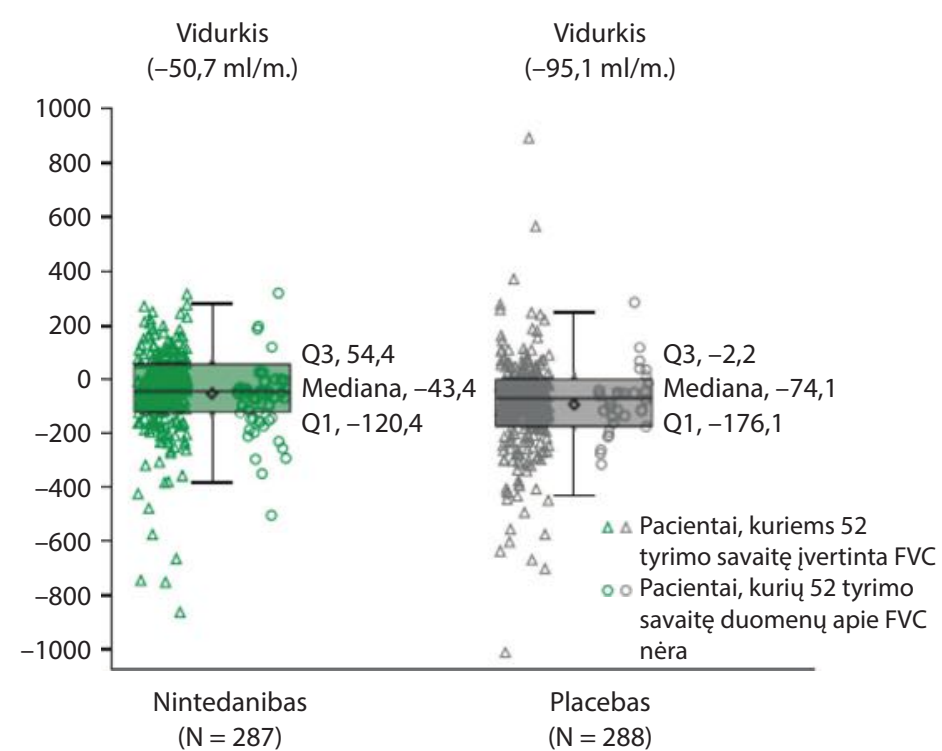

C

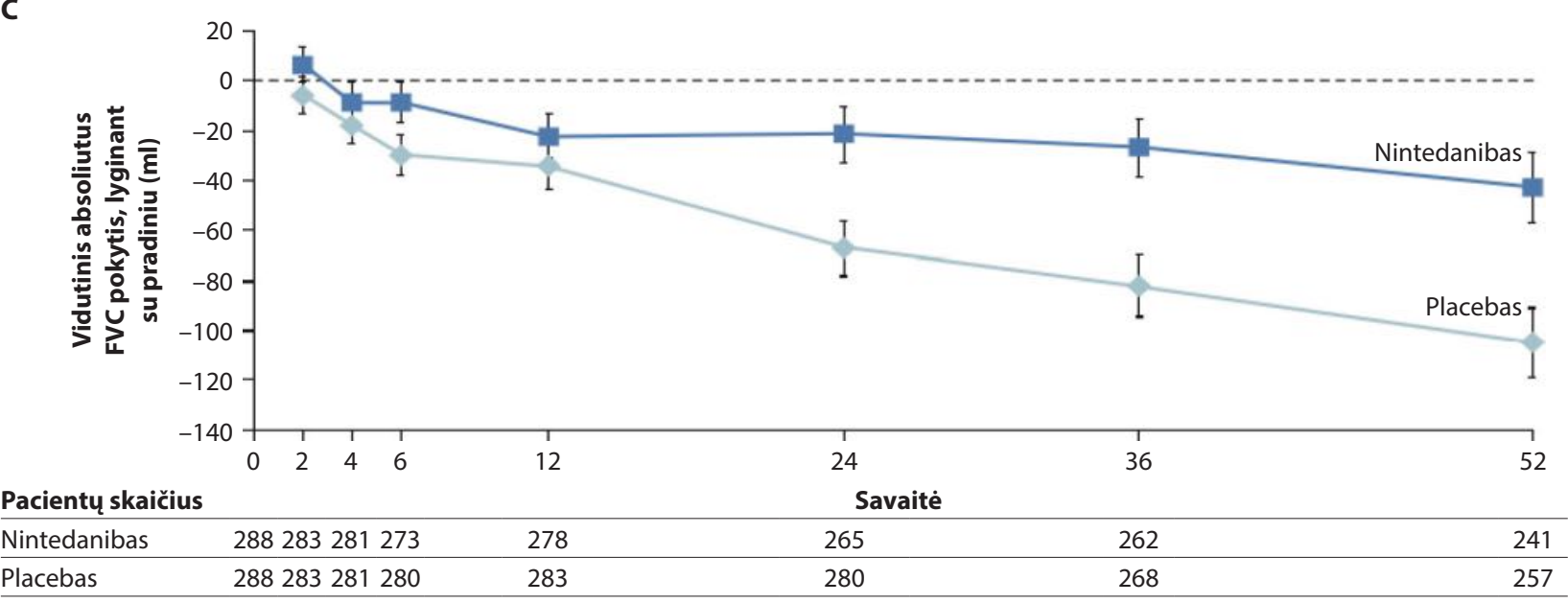

\section{1 pav. Forsuotos gyvybinès plaučių talpos sumažèjimas [22]}

(A) pateikiamas koreguoto metinio FVC sumažejimo greičio skirtumas tarp nintedanibo ir placebo grupių per 52 savaites. Duomenys apskaičiuoti su standartine paklaida. (B) pateikiami koreguoti metiniai FVC sumažejiimo greičiai per 52 savaites nintedanibo ir placebo grupèse. Q1 žymi pirmają kvartilę, Q3 - trečiają kvartilę. (C) pavaizduotas FVC pokytis, lyginant su pradiniu. Duomenys apskaičiuoti su standartine paklaida. FVC - forsuota gyvybinè plaučių talpa (angl. forced vital capacity).

(ịprasta intersticinè pneumonija arba kita intersticinių plaučių ligu grupè). Pirminè vertinamoji baigtis buvo metinis FVC sumažejimo greitis. Vertinta bendroji populiacija ir pacientai, kuriems radiologiškai buvo nustatytas îprastos intersticinès pneumonijos vaizdas.

Iš viso tyrime dalyvavo 663 pacientai (demografiniai ir svarbiausi klinikiniai duomenys pateikiami 3 lenteleje). Itraukti asmenys, kuriems nepaisant skiriamo gydymo kitais vaistiniais preparatais (bet ne nintedanibu ar pirfenidonu), per paskutinius 24 mèn. nustatytas bent vienas iš intersticinès plaučių ligos progresavimo kriterijų: santykinis FVC sumažèjimas ne mažiau kaip 10 proc. būtinojo dydžio, santykinis FVC sumažèjimas nuo 5 proc. iki <10 proc. būtinojo dydžio ir kvépavimo simptomų pablogejimas arba padidejjęs fibrozès plotas, remiantis didelès skiriamosios gebos kompiuterinès tomografijos duomenimis, arba kvèpavimo simptomų pablogejimas ir padidejęs fibrozès plaučiuose plotas. İtraukimo ị ty- rimą metu tiriamųjų FVC turèjo būti ne mažesnis kaip 45 proc. būtinojo dydžio, o $\mathrm{D}_{\mathrm{LCOc}}-$ nuo $30 \mathrm{iki}<80$ proc. būtinojo dydžio. Pacientai, kurie buvo gydomi azatioprinu, ciklosporinu, mikofenolato mofetiliu, takrolimusu, rituksimabu, ciklofosfamidu arba geriamaisiais gliukokortikoidais (>20 mg/d.), ị tyrimą neįtraukti. Po 6 mèn. tyrimo gydymo minètus vaistus buvo galima vartoti su sąlyga, jei kliniškai reikšmingai progresuoja intersticinẻ plaučių arba jungiamojo audinio liga.

Vertinant visus tyrime dalyvavusius asmenis, koreguotas FVC sumažėjimo greitis vartojant nintedanibą buvo $80,8 \mathrm{ml}$ per metus, vartojant placebo - 187,8 $\mathrm{ml}$ per metus; skirtumas tarp grupių - 107,0 ml per metus (95 proc. PI 65,4-148,5, p<0,001) (2 pav., 4 lentelè). Pacientams, turintiems radiologiškai tikètiną ịprastinę intersticinę pneumoniją, koreguotas FVC sumažèjimo greitis vartojant nintedanibą buvo 82,9 ml per metus, vartojant placebą - 211,1 ml per metus; skirtumas tarp 
2 lentelè. Nepageidaujami poveikiai* [22]

\begin{tabular}{|c|c|c|}
\hline \multirow{2}{*}{ lvykis } & $\begin{array}{c}\text { Nintedanibo } \\
\text { grupé } \\
(\mathbf{n}=\mathbf{2 8 8})\end{array}$ & $\begin{array}{c}\text { Placebo } \\
\text { grupé } \\
(n=288)\end{array}$ \\
\hline & \multicolumn{2}{|c|}{$\begin{array}{c}\text { Pacientų skaičius, } \\
\text { n (proc.) }\end{array}$} \\
\hline Bet koks nepageidaujamas poveikis & $283(98,3)$ & $276(95,8)$ \\
\hline \multicolumn{3}{|l|}{ Dažniausi nepageidaujami poveikiai † } \\
\hline Viduriavimas & $218(75,7)$ & $91(31,6)$ \\
\hline Pykinimas & $91(31,6)$ & $39(13,5)$ \\
\hline Odos opa & $53(18,4)$ & $50(17,4)$ \\
\hline Vèmimas & $71(24,7)$ & $30(10,4)$ \\
\hline Kosulys & $34(11,8)$ & $52(18,1)$ \\
\hline Nazofaringitas & $36(12,5)$ & $49(17,0)$ \\
\hline Viršutinių kvėpavimo takų infekcija & $33(11,5)$ & $35(12,2)$ \\
\hline Pilvo skausmas & $33(11,5)$ & $21(7,3)$ \\
\hline Nuovargis & $31(10,8)$ & $20(6,9)$ \\
\hline Svorio sumažèjimas & $34(11,8)$ & $12(4,2)$ \\
\hline Sunkus nepageidaujamas poveikis ‡ & $52(18,1)$ & $36(12,5)$ \\
\hline $\begin{array}{l}\text { Sunkius padarinius sukèlęs } \\
\text { nepageidaujamas poveikis § }\end{array}$ & $69(24,0)$ & $62(21,5)$ \\
\hline $\begin{array}{l}\text { Mirtimi pasibaigęs nepageidaujamas } \\
\text { poveikis }\end{array}$ & $5(1,7)$ & $4(1,4)$ \\
\hline $\begin{array}{l}\text { Nepageidaujamas poveikis, kai reikèjo } \\
\text { nutraukti dalyvavimą tyrime }\end{array}$ & $46(16,0)$ & $25(8,7)$ \\
\hline
\end{tabular}

*Nepageidaujami poveikiai per 52 tyrimo savaites bei 28 dienas po gydymo. † Dažniausiai pasitaikantys nepageidaujami poveikiai buvo tie, kurie pasireiškè $>10$ proc. tiriamujų bet kurioje grupeje.

‡ Sunkiu nepageidaujamu poveikiu vadintas îvykis, kuris sukèlè neiggaluma dirbti arba užsiimti iprasta veikla.

§Sunkius padarinius sukèlusiu nepageidaujamu poveikiu buvo apibrěžiamas jvykis, pasibaigęs mirtimi, keliantis pavoju gyvybei, kai reikejjo stacionarinio gydymo arba ilgesnès stacionarinio gydymo trukmès, sukèlęs nuolatinę arba kliniškai reikšmingą negalią arba nedarbingumą, fiksuota įgimta anomalija arba apsigimimas, arba yra kita sunki būklè dèl bet kokios kitos priežasties.

\section{3 lentelè. Pradiniai demografiniai ir klinikiniai visu IN BUILD tyrimo tiriamujų duomenys* [23]}

\begin{tabular}{|c|c|c|}
\hline Charakteristika & $\begin{array}{c}\text { Nintedanibo } \\
\text { grupé } \\
(\mathbf{n}=332)\end{array}$ & $\begin{array}{l}\text { Placebo } \\
\text { grupe } \\
(\mathbf{n}=331)\end{array}$ \\
\hline Moteriškoji lytis, n (proc.) & $179(53,9)$ & $177(53,5)$ \\
\hline Amžius, metais & $65,2 \pm 9,7$ & $66,3 \pm 9,8$ \\
\hline Rūkęs (-iusi) arba rūkantis (-i), n (proc.) & $169(50,9)$ & $169(51,1)$ \\
\hline $\begin{array}{l}\text { l ịprastinę intersticinę pneumoniją } \\
\text { panašūs radiologiniai požymiai, } \\
\text { vertinant DSGKT duomenis, n (proc.) }\end{array}$ & $206(62,0)$ & $206(62,2)$ \\
\hline $\begin{array}{l}\text { Ligos progresavimo kriterijai per } \\
\text { paskutinius } 24 \text { mėn., n (proc.) }\end{array}$ & $160(48,2)$ & $172(52,0)$ \\
\hline $\begin{array}{l}\text { Santykinis FVC sumažèjimas } \\
\geq 10 \text { proc. būtinojo dydžio }\end{array}$ & $110(33,1)$ & $97(29,3)$ \\
\hline $\begin{array}{l}\text { Santykinis FVC sumažèjimas nuo } \\
5 \text { proc. iki < } 10 \text { proc. būtinojo dydžio } \\
\text { ir kvėpavimo simptomų pasunkèji- } \\
\text { mas arba padidèjęs fibrozès laipsnis, } \\
\text { vertinant DSGKT duomenis }\end{array}$ & & \\
\hline $\begin{array}{l}\text { Kvėpavimo simptomu pasunkèjimas } \\
\text { arba padidèjęs fibrozès laipsnis, } \\
\text { vertinant DSGKT duomenis }\end{array}$ & $62(18,7)$ & $61(18,4)$ \\
\hline FVC, ml (proc. būtinojo dydžio) & $\begin{array}{c}2340 \pm 740 \\
(68,7 \pm 16,0)\end{array}$ & $\begin{array}{l}2321 \pm 728 \\
(69,3 \pm 15,2)\end{array}$ \\
\hline $\begin{array}{l}\text { DLCO, } \mathrm{mmol} / \mathrm{min} . / \mathrm{kPa} \text { (proc. būtinojo } \\
\text { dydžio) } \dagger\end{array}$ & $\begin{array}{c}3,5 \pm 1,2 \\
(44,4 \pm 11,9)\end{array}$ & $\begin{array}{c}3,7 \pm 1,3 \\
(47,9 \pm 15,0)\end{array}$ \\
\hline Bendras K-BILD klausimyno balas ₹ & $52,5 \pm 11,0$ & $52,3 \pm 9,8$ \\
\hline
\end{tabular}

Dıco - plaučiu difuzinis pajègumas anglies monoksidui (angl. diffusing capa city for carbon monoxide); DSGKT - didelès skiriamosios gebos kompiuterinè tomografija; FVC - forsuota gyvybinè plaučiu talpa (angl. forced vital capacity); K-BILD - Kingo trumpasis intersticinès plaučių ligos klausimynas (angl. King's Brief Interstitial Lung Disease Questionnaire); n - tiriamuju skaičius.

*duomenys pateikiami vidurkiu ir standartiniu nuokrypiu.

† DLCO vertè buvo koreguota atsižvelgiant į hemoglobino kiekį kraujyje. ‡ K-BILD klausimyno balai svyruoja nuo 0 iki 100; aukštesni balai rodo geresnè sveikatos būklè.

4 lentelè. Veiksmingumo vertinamos baigtys [23]

\begin{tabular}{|c|c|c|c|}
\hline Vertinamoji baigtis & $\begin{array}{c}\text { Nintedanibo } \\
\text { grupé }(n=332)\end{array}$ & $\begin{array}{l}\text { Placebo grupè } \\
(\mathbf{n}=331)\end{array}$ & $\begin{array}{l}\text { Skirtumas } \\
\text { (95 proc. PI) }\end{array}$ \\
\hline \multicolumn{4}{|l|}{ Pirminė vertinamoji baigtis } \\
\hline \multicolumn{4}{|l|}{ Metinis FVC sumažejimo greitis 52-ą tyrimo savaitę, $\mathrm{ml} / \mathrm{m}$. } \\
\hline Bendrojoje tyrimo populiacijoje & $-80,8 \pm 15,1$ & $-187,8 \pm 14,8$ & $107,0(65,4-148,5) \neq$ \\
\hline Pacientai, kurie turi ị iprastinę intersticinę pneumoniją panašių fibrozinių pokyčių & $-82,9 \pm 20,8$ & $-211,1 \pm 20,5$ & $128,2(70,8-185,6) \neq$ \\
\hline Pacientai, kurie turi kitų fibrozès plaučiuose požymių & $-79,0 \pm 21,6$ & $-154,2 \pm 21,2$ & $75,3(15,5-135,0) \S$ \\
\hline \multicolumn{4}{|l|}{ Antrinès vertinamosios baigtys } \\
\hline \multicolumn{4}{|c|}{ Absoliutus K-BILD balo pokytis per 52 tyrimo savaites, lyginant su pradine verte tyrimo pradžiojeף } \\
\hline Bendrojoje tyrimo populiacijoje & $0,55 \pm 0,60$ & $-0,79 \pm 0,59$ & $1,34(-0,31-2,98) \S$ \\
\hline Pacientai, kurie turi ị ipprastinę intersticinę pneumoniją panašių fibrozinių pokyčių & $0,75 \pm 0,80$ & $-0,78 \pm 0,79$ & $1,53(-0,68-3,74) \S$ \\
\hline \multicolumn{4}{|c|}{ Intersticinès plaučių ligos paūmèjimas arba mirtis per 52 tyrimo savaites, ìvykių skaičius, bendras skaičius (proc.) } \\
\hline Bendrojoje tyrimo populiacijoje & $26 / 332(7,8)$ & $32 / 331(9,7)$ & $0,80(0,48-1,34) \S \|$ \\
\hline Pacientai, kurie turi į iprastinę intersticinę pneumoniją panašių fibrozinių pokyčių & $17 / 206(8,3)$ & $25 / 206(12,1)$ & $0,67(0,36-1,24) \S \|$ \\
\hline
\end{tabular}




\section{Farmakoterapija}

\begin{tabular}{|c|c|c|c|}
\hline Vertinamoji baigtis & $\begin{array}{l}\text { Nintedanibo } \\
\text { grupè }(n=332)\end{array}$ & $\begin{array}{l}\text { Placebo grupé } \\
(\mathbf{n}=\mathbf{3 3 1})\end{array}$ & $\begin{array}{l}\text { Skirtumas } \\
\text { (95 proc. } \mathrm{PI})\end{array}$ \\
\hline \multicolumn{4}{|l|}{ Mirtis per 52 tyrimo savaites, $\mathrm{n}$ (proc.) } \\
\hline Bendrojoje tyrimo populiacijoje & $16 / 332(4,8)$ & $17 / 331(5,1)$ & $0,94(0,47-1,86) \S \|$ \\
\hline Pacientai, kurie turi i iprastinę intersticinę pneumoniją panašių fibrozinių pokyčių & $11 / 206(5,3)$ & $16 / 206(7,8)$ & $0,68(0,32-1,47) \S \|$ \\
\hline \multicolumn{4}{|l|}{ Papildomos vertinamosios baigtys iki pirmos duomenų analizès } \\
\hline \multicolumn{4}{|l|}{ Intersticinès plaučių ligos paūmèjimas arba mirtis, ivykių skaičius, bendras skaičius (proc.) } \\
\hline Bendrojoje tyrimo populiacijoje & $41 / 332(12,3)$ & $59 / 331(17,8)$ & $0,68(0,46-1,01) \S \|$ \\
\hline Pacientai, kurie turi i ịprastinę intersticinę pneumoniją panašių fibrozinių pokyčių & $28 / 206(13,6)$ & $44 / 206(21,4)$ & $0,61(0,38-0,98) \S \|$ \\
\hline \multicolumn{4}{|l|}{ Mirtis, ivykių skaičius/bendras skaičius (proc.) } \\
\hline Bendrojoje tyrimo populiacijoje & $27 / 332(8,1)$ & $38 / 331(11,5)$ & $0,70(0,43-1,15) \S \|$ \\
\hline Pacientai, kurie turi i iprastinę intersticinę pneumoniją panašių fibrozinių pokyčių & $20 / 206(9,7)$ & $31 / 206(15,0)$ & $0,63(0,36-1,10) \S \|$ \\
\hline
\end{tabular}

$\mathrm{PI}$ - pasikliautinasis intervalas.

* Pokytis nuo pradinio vizito, priklausomai nuo statistinio metodo, pateiktas vidurkiu \pm standartine klaida. Analizuotos dvi pagrindinès populiacijos bendroji tyrimo populiacija ir pacientai, kurie turi ị ịprastinę intersticinę pneumoniją panašių fibroziniais pokyčių.

† Pirminei vertinamajai baigčiai įvertinti turintiesiems i ịprastinę intersticinę pneumoniją panašių požymių i kiekvieną tyrimo grupę itraukta po 206 pacientus. Kitų fibrozės plaučiuose požymių turinčių tiriamujų grupèje buvo 126 asmenys, kuriems skirtas nintedanibas, 125 asmenys, kuriems skirtas placebas.

$\neq p<0,001$.

$\S$ Pasikliautinieji intervalai nustatyti ne visiems palyginimams, todèl galutinis gydymo poveikis nevertintas.

I Analizuojant K-BILD klausimyno balus bendrojoje tyrimo populiacijoje, 332 pacientai vartojo nintedanibą ir 330 pacientai placebą. Vertinant pacientu su i ịprastinę intersticinę pneumoniją panašiais fibroziniais pokyčiais populiaciją, analizuoti 206 pacientų nintedanibo grupeje ir 205 pacientų placebo grupeje duomenys.

|| Skirtumas jivertintas kaip rizikos santykis.

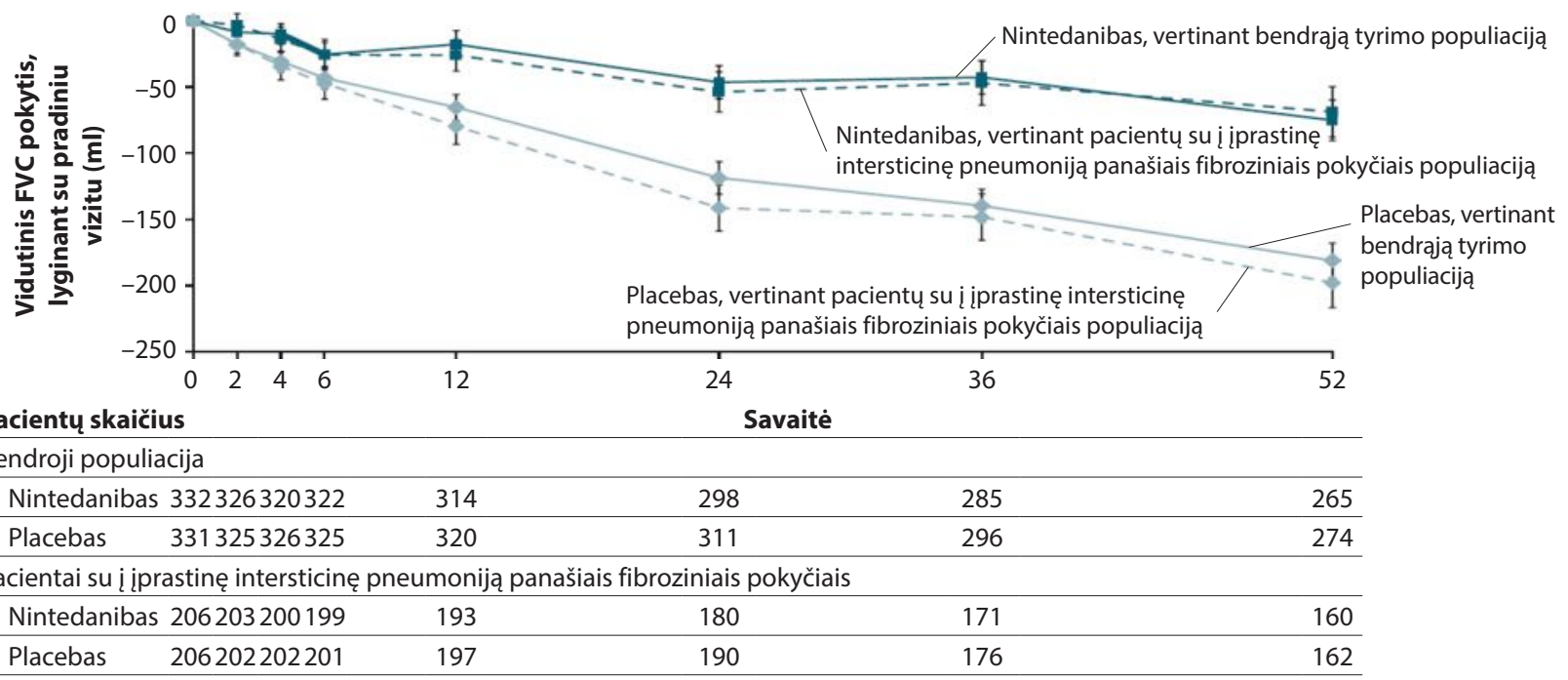

\section{2 pav. FVC sumažejimas per 52 tyrimo savaites lyginant su pradine verte [23]}

Pateiktas vidutinis FVC pokytis per 52 tyrimo savaites, palyginus su pradine verte. Analizuota visa tiriamuju populiacija ir atskirai vertinta pacientu su ị iprastinę intersticinę pneumoniją panašiais fibroziniais pokyčiais populiacija (patvirtinta atliekant didelès skiriamosios gebos kompiuterinès tomografijos tyrimą). Paveiksle esančios atskiros žymejjimo juostelès rodo standartinę paklaidą.

grupiu - 128,2 $\mathrm{ml}$ (95 proc. PI 70,8-185,6, p<0,001) (2 pav., 3 pav.). Duomenys apie vertinamụjų baigčiu rezultatus pateikiami 4 lentelèje. Dažniausias nepageidaujamas poveikis buvo viduriavimas, apie kuri pranešè 66,9 proc. nintedanibą vartojusių pacientų, 23,9 proc. placebo grupès tiriamųjų. Kepenų funkcijos sutrikimas dažniau nustatytas vartojusiems nintedanibą, palyginus su placebo grupe.

Taigi, intersticine plaučiu liga su progresuojančia fibroze sergantiems pacientams metinis FVC mažèjimo greitis buvo žymiai mažesnis nintedanibu gydytiems pacientams nei vartojusiems placebą.

\section{APIBENDRINIMAS}

Nintedanibas - tai viduląstelinis tirozino kinazès inhibitorius, priešfibroziškai veikiantis vaistas, patvirtintas idiopatinei plaučių fibrozei gydyti. Esminiai tokio gydymo aspektai: sulètinti ligos progresavimą, 


\section{Farmakoterapija}
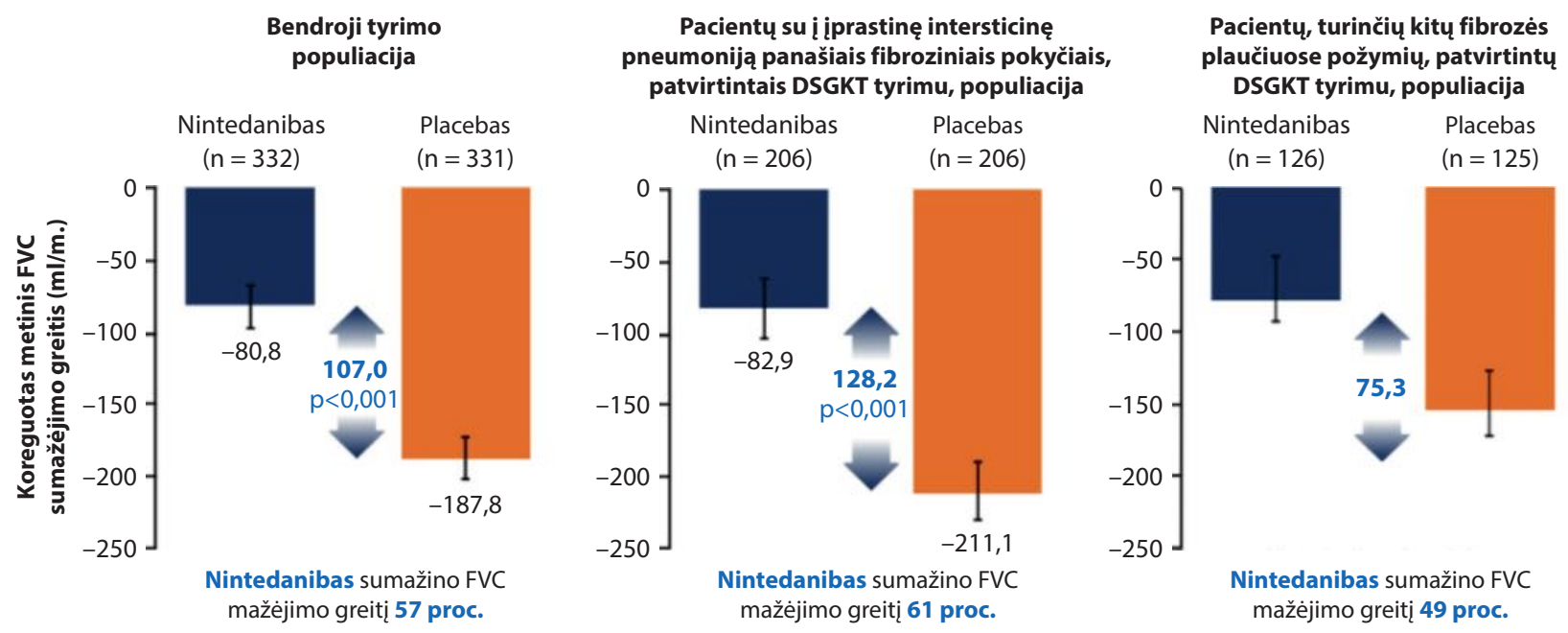

3 pav. Nintedanibo poveikis lètinti FVC mažèjimą palyginus su placebu [23]

DSGKT - didelès skiriamosios gebos kompiuterinè tomografija; FVC - forsuota gyvybinè plaučių talpa (angl. forced vital capacity).

forsuotos gyvybinès plaučių talpos mažèjimą, retinti ligos paūmejjimus. Tačiau idiopatinė plaučių fibrozė yra santykinai reta liga, o kitų fibrozuojančių intersticinių ligų daug, taigi, veiksmingo gydymo nèra. Itvertinus panašius patofiziologinius mechanizmus, atlikta tyrimų, vertinant nintedanibo veiksmingumą gydant su sistemine skleroze susijusią bei kitas ỉ îprastinę intersticinę pneumoniją panašiais fibrozuojančiais intersticines plaučių ligas. Pavyko reikšmingai sumažinti metinị forsuotos gyvybinès plaučių talpos mažejjimo greiti, sulètinti ligos progresavimo greiti, nekeičiant jau nustatyto vaisto saugumo profilio.

\section{LITERATŨRA}

1. Wollin L, Wex E, Pautsch A, Schnapp G, Hostettler KE, Stowasser S, et al. Mode of action of nintedanib in the treatment of idiopathic pulmonary fibrosis. Eur Respir J. 2015;45:1434-45.

2. Richeldi L, Costabel U, Selman M, Kim DS, Hansell DM, Nicholson AG, et al. Efficacy of a tyrosine kinase inhibitor in idiopathic pulmonary fibrosis. N Engl J Med. 2011;365:1079-87.

3. Richeldi L, du Bois RM, Raghu G, Azuma A, Brown KK, Costabel U, et al. Efficacy and safety of nintedanib in idiopathic pulmonary fibrosis. N Engl J Med. 2014;370:2071-82.

4. Rodriguez-Portal JA. Efficacy and safety of nintedanib for the treatment of idiopathic pulmonary fibrosis: an update. Drugs R D. 2018;18(1):19-25.

5. Richeldi L, Kreuter M, Selman M, Crestani B, Kirsten AM, Wuyts WA, et al. Long-term treatment of patients with idiopathic pulmonary fibrosis with nintedanib: results from the TOMORROW trial and its open-label extension. Thorax. 2018;73(6):581-3.

6. Richeldi L, Cottin V, Bois RM, Selman M, Kimura T, Bailes Z, et al. Nintedanib in patients with idiopathic pulmonary fibrosis: Combined evidence from the TOMORROW and INPULSIS trials. Respir Med. 2016;113:74-9.

7. Kikuchi K, Kadono T, Ihn H, Sato S, Igarashi A, Nakagawa H, et al. Growth regulation in scleroderma fibroblasts: increased response to transforming growth factor-beta 1. J Invest Dermatol. 1995; 105:128-32.

8. Hsu E, Shi H, Jordan RM, Lyons Weiler J, Pilewski JM, FeghaliBostwick CA. Lung tissues in patients with systemic sclerosis have gene expression patterns unique to pulmonary fibrosis and pulmonary hypertension. Arthritis Rheum. 2011; 63:783-94.

9. Lam AP, Flozak AS, Russell S, Wei J, Jain M, Mutlu GM, Budinger GR, et al. Nuclear $\beta$-catenin is increased in systemic sclerosis pulmonary fibrosis and promotes lung fibroblast migration and proliferation. Am J Respir Cell Mol Biol. 2011; 45:915-22.
10. Huang J, Maier C, Zhang Y, Soare A, Dees C, Beyer C, et al. Nintedanib inhibits macrophage activation and ameliorates vascular and fibrotic manifestations in the Fra2 mouse model of systemic sclerosis. Ann Rheum Dis. 2017; 76:1941-8.

11. Hostettler KE, Zhong J, Papakonstantinou E, Karakiulakis G, Tamm M, Seidel P, et al. Anti-fibrotic effects of nintedanib in lung fibroblasts derived from patients with idiopathic pulmonary fibrosis. Respir Res. 2014;15:157.

12. Wollin L, Maillet I, Quesniaux V, Holweg A, Ryffel B. Antifibrotic and antiinflammatory activity of the tyrosine kinase inhibitor nintedanib in experimental models of lung fibrosis. J Pharmacol Exp Ther. 2014;349:209-20.

13. Huang J, Beyer C, Palumbo-Zerr K, Zhang Y, Ramming A, Distler A, et al. Nintedanib inhibits fibroblast activation and ameliorates fibrosis in preclinical models of systemic sclerosis. Ann Rheum Dis. 2016;75:883-90.

14. Ackermann M, Kim YO, Wagner WL, Schuppan D, Valenzuela CD, Mentzer SJ, et al. Effects of nintedanib on the microvascular architecture in a lung fibrosis model. Angiogenesis. 2017;20:359-72.

15. Redente EF, Aguilar MA, Black BP, Edelman BL, Bahadur AN, Humphries SM, et al. Nintedanib reduces pulmonary fibrosis in a model of rheumatoid arthritis associated interstitial lung disease. Am J Physiol Lung Cell Mol Physiol. 2018;314: L998-L1009.

16. Wollin L, Distler JHW, Denton CP, Gahlemann M. Rationale for the evaluation of nintedanib as a treatment for systemic sclerosis-associated interstitial lung disease. J Scleroderma Relat Disord. 2019;4(3):212-8.

17. Wells AU, Brown KK, Flaherty KR, Kolb M, Thannickal VJ. What's in a name? That which we call IPF, by any other name would act the same. Eur Respir J. 2018;51(5): 1800692.

18. Wollin L, Distler JHW, Redente EF, Riches DWH, Stowasser S, Schlenker-Herceg R, et al. Potential of nintedanib in treatment of progressive fibrosing interstitial lung diseases. Eur Respir J. 2019;54(3).

19. Moore OA, Proudman SM, Goh N, Corte TJ, Rouse H, Hennessy $\mathbf{O}$, et al. Quantifying change in pulmonary function as a prognostic marker in systemic sclerosis-related interstitial lung disease. Clin Exp Rheumatol. 2015;33(91):S111-6.

20. Goh NS, Hoyles RK, Denton CP, Hansell DM, Renzoni EA, Maher TM, et al. Short-term pulmonary function trends are predictive of mortality in interstitial lung disease associated with systemic sclerosis. Arthritis Rheumatol. 2017;69:1670-8.

21. Goh NS, Desai SR, Veeraraghavan S, Hansell DM, Copley SJ, Maher TM, et al. Interstitial lung disease in systemic sclerosis: a simple staging system. Am J Respir Crit Care Med. 2008; $177: 1248-54$

22. Distler O, Highland KB, Gahlemann M, Azuma A, Fischer A, Mayes MD, et al. Nintedanib for Systemic Sclerosis-Associated Interstitial Lung Disease. N Engl J Med. 2019;380(26): 2518-28.

23. Fabre A, Nicholson AG. Nintedanib in Progressive Fibrosing Interstitial Lung Diseases. N Engl J Med. 2020;382(8):780. 